\section{DIGITAL COMMONS \\ @ UNIVERSITY OF SOUTH FLORIDA}

\section{ABO: Interactive Journal for Women in the Arts, 1640-1830}

Volume 7

Issue 2 Volume 7.2 (Fall 2017)

Article 4

2017

\title{
WWABD? Intersectional Futures in Digital History
}

Tonya L. Howe

Marymount University, thowe@marymount.edu

Follow this and additional works at: https://digitalcommons.usf.edu/abo

Part of the Digital Humanities Commons, Educational Methods Commons, Feminist, Gender, and Sexuality Studies Commons, Literature in English, British Isles Commons, and the Theatre and Performance Studies Commons

\section{Recommended Citation}

Howe, Tonya L. (2017) "WWABD? Intersectional Futures in Digital History," ABO: Interactive Journal for Women in the Arts, 1640-1830: Vol.7: Iss.2, Article 4.

http://doi.org/10.5038/2157-7129.7.2.1166

Available at: https://digitalcommons.usf.edu/abo/vol7/iss2/4

This Digital Humanities is brought to you for free and open access by Digital Commons @ University of South Florida. It has been accepted for inclusion in ABO: Interactive Journal for Women in the Arts, 1640-1830 by an authorized administrator of Digital Commons @ University of South Florida. For more information, please contact digitalcommons@usf.edu. 


\title{
WWABD? Intersectional Futures in Digital History
}

\author{
Abstract \\ WWABD: What would Aphra Behn-world traveler and spy, playwright and poet of scandal, innovator of \\ novelistic forms-do, were she to imagine a future for digital humanities in period-specific scholarship? \\ This essay outlines a vision for the DH section of Aphra Behn Online: An Interactive Journal for Women in \\ the Arts, 1640-1830. In particular, I see three important and interrelated places for development: \\ theorizing the feminized labor of digital recovery, editing, and textual preparation; offering thoughtful and \\ feminist approaches to digital pedagogy that are specific to the work we do in the period; and critically \\ assessing the absences in existing digital projects. Our digital future needs to foster flexibility, \\ experimentation, and intersectional thinking.

\section{Keywords} \\ digital humanities, intersectionality, intersectional futures, Aphra Behn, long eighteenth century \\ Creative Commons License \\ (c) (i) (8)
}

This work is licensed under a Creative Commons Attribution-Noncommercial 4.0 License 


\section{WWABD? Intersectional Futures in Digital History}

Whether as Aphra Behn Online or ABO: Interactive Journal for Women in the Arts, 1640-1830, this journal has long been committed to rethinking women's writing of the long eighteenth century as it enters into the consciousness of the twenty-first. Since our first issue in 2011, $A B O$ has seen itself as a scholarly journal that is conscious of - and conscientious about-its potential to reshape feminist approaches to women's writing by way of the digital environment; the Internet gave us the ability to launch one of the very first such journals. In many ways, then, the work of $A B O$ is the work of feminist literary history itself. As an open access and yet rigorously and partially-open peer-reviewed journal in period-specific humanities, we have always been committed to making marginalized voices more central to the scholarly conversation. What was cutting edge in 2011, however, feels somehow in 2017 much less so.

When $A B O$ began, our Digital Humanities section was called New Media - a place for scholarly work at the intersection of media, women, and the long eighteenth century. The shift from New Media to Digital Humanities has enabled us to enter into broader conversations about how meaning is made and re-made in an interconnected environment. A variety of tools and datasets are now available for scholars to do the work of distant reading on large swathes of literary output_-Voyant Tools, Mallet tools for topic modeling, and so on. Authorship studies, digitization and archiving, electronic editing, digital analysis, physical fabrication, mechanical remediation and re-/de-formation for purpose: ours is an exciting time for scholars and makers. But, with this renaming comes other challenges. One of the most important debates in digital humanities has been that of scale, inclusion, and niche (Klein and Gold). The definitional instability of the field is, indeed, one of its most frustrating and productive qualities. The methodological approaches and acts of making and sharing that characterize digital humanities are deeply interdisciplinary and collaborative, and the field is expanding on an almost daily basis. Despite this expansion, and despite the energy of so-called "Big Tent" approaches, it is also true that digital humanities in academe has encountered difficulties of inclusion and asymmetries in the global-local landscape (Risam). Scholars and activists have been vocal in advocating for truly decentralized digital humanities and projects that re-center geographic, linguistic, and ethnic diversity. Today, however, such projects still remain at the margins.

In the world of Early Modern women in the arts, scholarly publication in digital humanities has also remained relatively rare. As a test case, a brief search for articles related to the eighteenth century in Digital Humanities Quarterly, a significant publication in non-period-specific digital humanities, results in only twenty articles and reviews. Of those, a mere handful are in any way focused on gender or women. The challenges of working in period-specific context focusing exclusively on women illuminates, perhaps, some of the broader difficulties of scale and inclusion that digital humanities as an emergent field grapples with. Given the narrow focus of the journal on women in the arts, 1640-1830, a further narrowing into a field that is itself faced with problems both of definition and inclusion makes our work here unclear in some ways-but it also helps outline the shape of our future.

The future of $A B O$ must be one of intersectionality, in all ways. In the Digital Humanities section, we must take special care to advocate for intersectionality in the way we approach our question of scale and topic. How can we draw on the lessons of intersectional feminism-so 
vividly described by Mona Narain in her vision statement - to inform our approach to publishing current scholarly work at the intersection of digital humanities and gender in the Early Modern period? $A B O$ is one of the only peer-reviewed, scholarly venues for this kind of work. We have already diversified the word count for our submissions to engage and enable an agile scholarship that can respond "just in time" to emerging conversations. As Digital Humanities section editor for $A B O$, I see three important and interrelated places for development: theorizing the feminized labor of digital recovery, editing, and textual preparation; offering thoughtful and feminist approaches to digital pedagogy that are specific to the work we do in the period; and critically assessing the absences in existing digital projects.

Some conversations in digital humanities are and will remain especially relevant for our mission: issues of accessibility, digitization, searchability, markup, and discoverability. While the pioneering feminist historiographers of the 1970s and 1980s made the first essential sallies, this work is not yet done, though digital methods give us more access to work of forgotten women. Since the early 1990s and the advent of the World Wide Web, digital literary studies took off. The Women Writers Project, which started at Brown University and is now a part of the Digital Scholarship Group at Northeastern University, began in 1998 and went online a decade latertoday, it is perhaps the most well-known and respected site not merely for the recovery work of feminist historiographers, but also for the production of accessible, machine-readable texts that are available for scholars to work with in new ways. The 2010 launch of "TypeWright," in conjunction with 18thConnect, has made it possible to crowdsource OCR correction and move more reliable texts into the public domain. With the widespread use of TEI as a markup standard, machine-readable texts are more and more available, though the quality and provenance of the material is not always clear outside of the aura granted by persistent and well-funded projects. Clearly, we should be advocating for and doing scholarly work with projects that foreground the voices of women - but we need to be doing more.

One place that digital humanities work around women and the long eighteenth century has been notably innovative is in database creation, public humanities, and other forms of what Sarah Blackwood and Lauren Klein call carework- "the subset of feminized reproductive labor that is undertaken out of a sense of compassion with or responsibility for others." Editing is a particularly important form of carework for us here at $A B O$. Typically undertaken by women, it is also as typically under-represented in discussions of scholarship and, as Blackwood calls it, the "individualist/genius logic of the academy." Because so much of our labor as teachers, feminist scholars, and historiographers involves recovery and pedagogy, it is imperative that we advocate for taking care of our carework, advocate for its scholarly value, and make it visible in all the ways it can and should be visible. How can we theorize the editorial work of women in the long eighteenth century using the practices and methods of digital humanities?

While women are still under-represented in digital humanities scholarship and projects of critical making, our voices are strong in the fields of digital pedagogy. Despite the irony that teaching, which we all do in academia, should be the first thing we theorize, the scholarship of pedagogy is often itself marginalized. The academic position of digital pedagogy is at best second-classed, and at worst ignored in research-focused contexts, as Stephen Brier has pointed out. This marginalization has profound implications not only for how we teach but also for how we prepare a new generation of students and scholars. Similarly, the reality of community colleges, 
which serve nearly half of all the undergraduate students in the United States, is also notoriously under-represented in digital humanities. How can we embrace the big tent potential of digital humanities while not losing our focus on women in the arts, given the under-representation of women and people of color in the field more broadly?

Since so much of our carework is pedagogical in nature, it is imperative that the scholarship of digital pedagogy be more visible as scholarship. While $A B O$ is particularly strong in the scholarship of pedagogy, I think there is room for more fully-theorized essays taking up the scholarship of digital pedagogy. What can the modes of seeing and thinking common to digital humanities bring to bear on how we do what we do in the classroom - and what we might not be doing? What does a feminist, historically-minded, digital pedagogy look like? How do we educate the next generation of scholars to ask the questions we have not yet begun to ask, especially about women and gender? Physical fabrication is a fascinating possibility for questions under this rubric - how can we draw on emerging technologies of 3-D printing, for instance, to help make real for our students women's lived experience in the long eighteenth century? What about the physical making of book technology?

And finally, $A B O$ offers a unique platform for feminist scholarship that critically assesses the gaps in eighteenth-century digital projects. I think there is a real need to look at how existing digital archives and projects focusing on the long eighteenth century broadly enable us to askor disable us from asking - questions about women, gender, and sexuality. How might we read existing databases and applications against the grain for what they reveal or conceal about gender in the period? On a related note, we also need to be thinking hard about how digital humanities can shine new light on the history and creativity of women and people of color in the long eighteenth century, both locally and globally. What projects and voices do we need, and how can we best support them? What looks different if we use digital methods to put those at the margins at the center of Enlightenment histories?

The questions I ask here are opening volleys: what other questions can be asked? WWABD: What would Aphra Behn - world traveler and spy, playwright and poet of scandal, innovator of novelistic forms - do? Under my editorship, I hope that the Digital Humanities section of $A B O$ can build on and renew the work interrogating women's writing in electronically-sensitive ways. Paradoxically, an $A B O$ of the future needs to foster flexibility, experimentation, and intersectional thinking to persist in its niche.

Tonya Howe

Marymount University 


\section{Works Cited}

Blackwood, Sarah. "Editing as Carework: The Gendered Labor of Public Intellectuals." Avidly, 6 June 2014, avidly.lareviewofbooks.org/2014/06/06/editing-as-carework-the-genderedlabor-of-public-intellectuals/. Accessed 12 Oct. 2017.

Brier, Stephen. "Where's the Pedagogy? The Role of Teaching and Learning in the Digital Humanities." Debates in the Digital Humanities, ed. Lauren F. Klein and Matthew K. Gold, U of Minnesota P, 2016, dhdebates.gc.cuny.edu/debates/text/8. Accessed 12 Oct. 2017.

Franzini, Greta, ed. "Göttingen Dialog in Digital Humanities." Digital Humanities Quarterly, Alliance of Digital Humanities Organizations, digitalhumanities.org/dhq. Accessed 12 Oct. 2017.

Klein, Lauren F. "The Carework and Codework of the Digital Humanities." The Digital Antiquarian Conference, 29 May 2015, Worcester, MA, lklein.com/2015/06/thecarework-and-codework-of-the-digital-humanities/. Accessed 12 Oct. 2017.

Klein, Lauren F., and Matthew K. Gold. "Digital Humanities: The Expanded Field." Debates in the Digital Humanities, ed. Lauren F. Klein and Matthew K. Gold, U of Minnesota P, 2016, dhdebates.gc.cuny.edu/debates/2. Accessed 12 Oct. 2017.

Risam, Roopika. "Navigating the Global Digital Humanities: Insights from Black Feminism." Debates in the Digital Humanities, ed. Lauren F. Klein and Matthew K. Gold, U of Minnesota P, 2016, dhdebates.gc.cuny.edu/debates/text/80. Accessed 12 Oct. 2017.

"TypeWright." 18thConnect, Initiative for Digital Humanities, Media, and Culture, Texas A\&M U, www.18thconnect.org/typewright/documents. Accessed 12 Oct. 2017.

Women Writers Project. Digital Scholarship Group, Northeastern U, wwp.northeastern.edu. Accessed 12 Oct. 2017. 